\title{
Kvindegymnastik, scenisk dans og kvinders medborgerskab i 1920erne og 1930erne
}

Af Anne Lykke Poulsen og Karen Vedel

Trods grundlæggende forskelle mellem scenisk dans og rytmisk gymnastik i forhold til funktion, formål og kulturhistorisk udvikling er det muligt at identificere betydningsfulde fællestræk. Udgangspunktet i begge aktiviteter er en form for kropslig udfoldelse, der er forbundet med forestillinger om kroppens såvel som tankens kultivering. Både dans og rytmisk gymnastik kan vises frem for et publikum. Den rytmiske gymnastik i Danmark har i de seneste årtier hentet inspiration i forskellige danseretninger som moderne dans, hip-hop, jazz dans m.m. Men overlappet mellem dans og gymnastik har også historiske rødder. Inden for visse gymnastiktraditioner blev der eksperimenteret med dansens former allerede $\mathrm{i}$ begyndelsen af 1900-tallet. På Paul Petersens gymnastikinstitut blev der undervist og givet opvisninger i slørdans, ballet og plastik. ${ }^{1}$ Disse bevægelsesformer blev den gang og siden modtaget højst forskelligt af gymnastikpublikum med reaktioner fra begejstring til miskendende kommentarer om »falsk Gratie«, »Affektation« og »ugymnastiske Kunster og Fiksfakserier «. ${ }^{2}$

Som henholdsvis danse- og idrætsforsker samarbejdede vi for et par år siden om et fælles oplæg på Kulturministeriets årlige idrætsforskningskonference om dette overlap mellem dans og gymnastik. Udgangspunktet var en undren over de mange ligheder imellem to kvinder, som i 1920erne etablerede sig som aktører i henholdsvis scenedansen og kvindegymnastikken; nemlig koreografen, danseren og dansepædagogen Jenny Møller og gymnastiklærerinden Agnete Bertram. Begge kvinder indtog en form for særstatus i deres felt. Begge fik desuden i kraft af deres pædagogiske virke betragtelig indflydelse i deres samtid og er alligevel blevet overset eller marginaliseret $\mathrm{i}$ den hidtidige historieskrivning inden for deres respektive fag. Da Jenny Møller aldrig virkede ved balletten, der her forstås som institutionen Den Kongelige Danske Ballet, er hun hidtil 'faldet ud' af scenedansens historie, der hidtil er blevet fortalt som ballettens historie. Agnete Bertram blev nok anerkendt i sin samtid, men er alligevel blevet tilskrevet en marginal betydning i idrætshistorien. På trods af, at de to pædagoger identificerer sig som tilhørende forskellige kropskulturelle genrer, vil vi i det følgende benytte dem som afsæt for en undersøgelse af slægtskabet mellem scenisk dans og kvindegymnastik i 1920erne og 1930erne.

Formålet med artiklen er at unders $\varnothing$ ge det historiske overlap mellem dans og kvindegymnastik. Der bliver taget afsæt i det bevægelsesmæssige indhold af henholdsvis Jenny Møllers dans og Agnete Bertrams kvindegymnastik, hvilket leder til en bestemmelse af den position, de hver især indtager i deres respektive felter. ${ }^{4}$ Herefter diskuteres de to kropskulturelle former i et genreanalytisk perspektiv. I overensstem- 
melse med intentionen om at forstå de to pædagoger i en bredere kulturel og samfundsmæssig kontekst leder diskussionen frem til en konkretisering af scenedans og kvindegymnastik som arenaer for udvikling af kvindeligt medborgerskab.

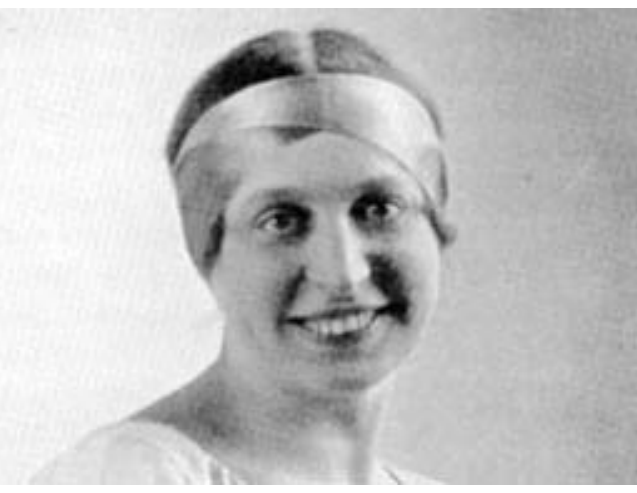

Agnete Bertram (1893-1983).

- Kom fra et københavnsk middelklassehjem. Faren var arkitekt og moren var lærer. Gift med gymnastiklærer N.D.C. Petersen i 1925.

- Studentereksamen fra Marie Kruses skole 1912.

- Cand. mag. i dansk, engelsk og gymnastik i 1920. Første kvinde med bifag i gymnastik.

- »Universitetsgymnastiklærerinde « i Universitetets Studenter Gymnastikforening (USG) 1920-66, og gymnastikinspektrice samme sted 1943-1966.

- Åbnede i 1920 Agnete Bertram KvindeGymnastikskole, som hun drev sammen med sin mand indtil 1942. Udvidet med en etårig gymnastiklærerindeuddannelse 192833.

- Elever af Agnete Bertram oprettede efterhånden Bertram-skoler i København og 25 andre danske byer.

- Gav siden debuten i 1918 utallige gymnastikopvisninger i Danmark og på rejser i udlandet.

- Modtog Ling-medalje i 1939. Udnævnt til Ridder af Dannebrog i 1958. Biograferet i Dansk Biografisk Leksikon og Dansk Kvindebiografisk Leksikon.

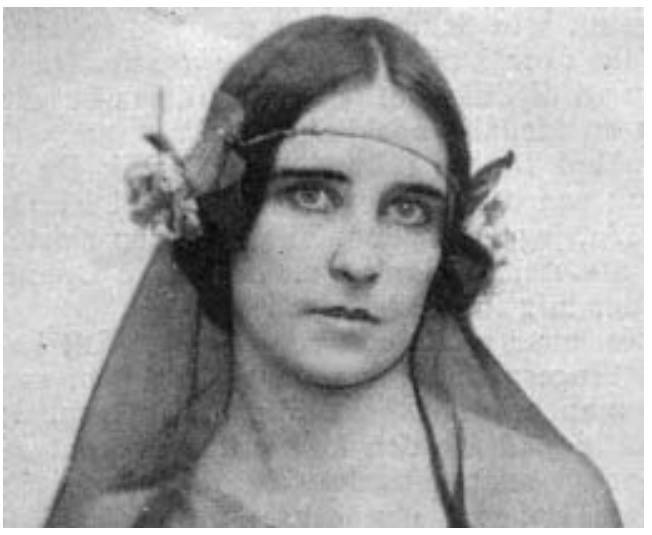

Jenny Møller (1892-1952).

- Kom fra et middelklassehjem, der var præget af en stærk interesse for kunst. Faderen, som var af præsteslægt, var selv bogholder.

- Blev efter faderens ønske meldt ind på Nathalie Zahles Seminarieskole. Sprang fra seminarieuddannelsen til fordel for en privat uddannelse som danser, koreograf og lærerinde i plastik.

Professionsforberedende træning i København 1910-1919 inden for bevægelsessystemer som Calisthenics og Dalcroze-teknik $^{3}$, suppleret med tegneundervisning på Glyptoteket og balletundervisning hos den kongelige balletdanserinde og koreograf Emilie Walbom (1858-1932). Desuden elev hos den russiske balletmester Michail Fokin (1880-1942) under hans ophold i Danmark 1918-1919.

- Etableret som underviser i 1919. Oprettede i 1927 Jenny Møllers Danse Studie, der uddannede danserinder og danselærerinder. Ved Jenny Møllers død i 1952 havde skolen ca. 100 elever.

- Virkede som koreograf. I 1921 stod hun for dansene til Max Reinhardts iscenesættelse af 'En Skcersommernatsdrøm' på Grosses Schauspielhaus i Berlin. I en årrække koreograferede hun desuden til Friluftsteatret i Dyrehaven, ligesom hun tilbagevendende stod for danseopvisninger på bl.a. Det Ny Teater, Casino, i d'Angleterres Palmehave og på Glyptoteket.

- Forblev ugift og delte privatbolig med søsteren, som var pianist ved danseskolen. 


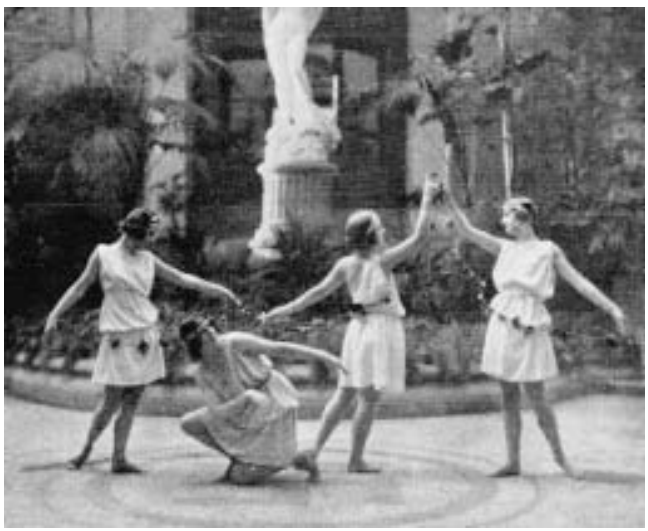

Jenny Moller afholdt ofte sine elevopvisninger i Glyptoteket, hvor det plastiske udtryk, der pragede hendes undervisning, kom til sin ret omgivet af antikkens skulpturer. I billedet fra 1928 poserer Jenny Møller (siddende) for fotografen sammen med tre elever $i$ en nøje komponeret frise. Det individuelle udtryk er betonet, idet ikke to af danserinderne indtager samme position. De bare fødder, de grask-inspirerede dragter og hårbånd sammen med armenes og ryggens udtryksfuldhed understreger de klassiske idealer om naturlighed, skønhed og harmoni. Benene indtager en stilling, der i Jenny M $\phi-$ lers terminologi kaldes 'den antikke hvilestilling'. Kilde: Vore Damer 30. 03.1928

\section{Kvindegymnastik og det $k v i n d e l i g e ~ i$ dansen}

I et socialkonstruktivistisk perspektiv har kvinders deltagelse i dans, gymnastik og idræt gennem tiden bidraget til den sociale konstruktion af kvindelighed, ${ }^{6}$ det vil sige, de normer om kvindelige egenskaber og samfundsmæssige opgaver og funktioner, som til forskellige tider, er blevet knyttet til kvindekønnet. ${ }^{7}$ Hvordan bidrog Agnete Bertram og Jenny Møller igennem deres bevægelsessystemer til at konstruere kvindelighed?

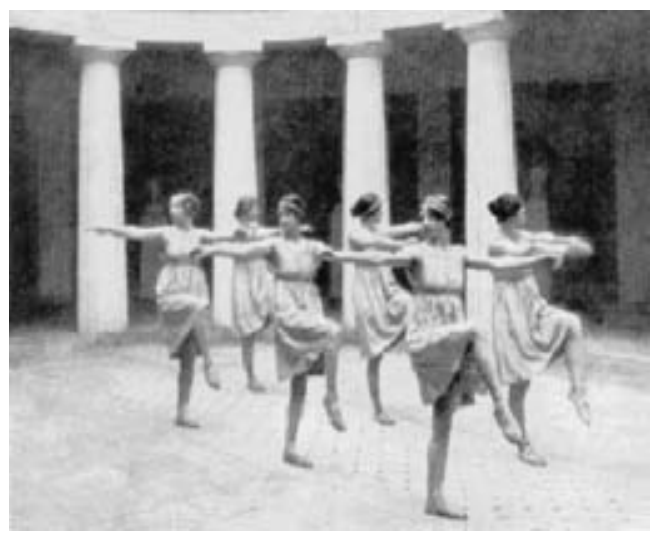

Med den første danske gymnastikfilm $»$ En $\emptyset$ velsestime på Frk. Agnete Bertrams Kvinde-Gymnastikskole« $i 1923$ opnåede Agnete Bertram megen omtale i den $k \phi$ benhavnske presse. Filmen blev optaget $i$ Carlsbergs aresbolig på Valby Bakke. Den rumlige iscenesattelse understregede gymnastikkens astetiske udtryk. Gymnasterne var klcedt i karakteristiske lyse og fjerlette silketunikaer, som understøttede rummets antikke graske stemning. Det samme gjaldt de enkelte фvelsers navne, såsom »diskos" og »vasen«. ${ }^{5}$ Kilde: Johannes Lindhard, Den specielle Gymnastikteori, Kobenhavn 1927.

Nøgleordene i Agnete Bertrams gymnastik var videnskabelighed og kvindelighed. Under uddannelsen på Statens Gymnastikinstitut oplevede Agnete Bertram et modsætningsforhold mellem den praktiske undervisning i svensk gymnastik og den teoretiske undervisning i fysiologi, som blev varetaget af fysiologen, docent og siden professor ved Statens Gymnastikinstitut Johannes Lindhard. Agnete Bertram satte sig for at udvikle en kvindegymnastik, der var i overensstemmelse med Lindhards videnskabelige principper. Det bevægelsesmæssige udgangspunkt var stadig 
svensk gymnastik, men Agnete Bertram tilføjede en æstetisk dimension, som handlede om funktionalitet snarere end ekspressivitet: »[Der] ligger i Udførelsen af hver $\emptyset$ velse og $i$ Ønsket om at udføre den saa godt som muligt et vigtigt sjoleligt Moment [..] Se det er dette hygiejniske Princip, der efter min Mening bør vare Maalet med al Gymnastik, men i Udforelsen maa man tage alt Hensyn ogsaa til Skønheden, fordi intet ukønt kan virke sjoleligt opbyggende og tilfredsstillende. ${ }^{8}$ Hendes gymnastik tog dels udgangspunkt i forestillingen om den kvindelige særart, dels var den inspireret af dagligdags »naturlige « bevægelser. Bevægelserne skulle være harmoniske, bløde, rytmiske og sammenhængende, thi »Først naar Øvelser er udslag af naturlig Rytme og Energiforbrug, kan de blive alment opdragende, og forst da har de ogsaa Skфnhed «. ${ }^{9}$ De fritstående øvelser var grundlaget i Agnete Bertrams kvindegymnastik. Med undtagelse af ligevægtsbommen anvendte hun ikke gymnastikkens traditionelle redskaber. Øvelserne til ligevægtsbommen var konstrueret i overensstemmelse med Lindhards videnskabelige argumenter om, at ligevægtsøvelser var særdeles egnede for kvinder, som med deres lavere tyngdepunkt og bedre koordinationsevne havde særlige forudsætninger for disse $\emptyset$ velser. ${ }^{10}$

Til forskel fra kvindegymnastikken fremstår kvindelighed i danse- og balletskolernes undervisning som en kvalitet, der oftest er implicit. Helt undtagelsesvis finder vi hos Emilie Walbom, en af datidens betydeligste balletpædagoger i K $\varnothing$ benhavn, et udtalt kønspersperktiv, der formuleres som en modvilje mod at undervise mænd. I et interview fra 1912, gjorde Walbom gældende, at hun slet ikke synes, at »mandfolk og dans horer sammen « og at fremtidens dans, efter hendes mening, bur- de udføres af kvinder. ${ }^{11}$ Synspunktet blev uddybet $i$ et senere interview med en udtalelse om, at plastik og dans efter hendes opfattelse kunne betragtes som en særlig kvindelig form for motionsgymnastik. ${ }^{12}$

Gennem hele sin pædagogiske virksomhed lagde Jenny Møller vægt på plastik. At hendes undervisning af voksne samtidig var målrettet mod kvinder fremgik indirekte af programmerne fra hendes dansestudie. I begyndelsen af 1930erne annoncerede hun f.eks. med undervisning af 'ungpige hold', 'frue hold (motionsplastik)' og 'danserinde (lærerinde) uddannelse'. Hvorledes undervisningen i plastik og dans udover at være målrettet til forskellige aldersgrupper henvendte sig til forskellige ambitionsniveauer, fremgår af følgende uddrag fra danseskolens programtekst: »... Tratte og forlaste unge Piger genvinder ved den plastiske Legemstraning deres Form kommer $i$ Vigeur - Fruer bevarer ved den deres Ungdom og Smidighed og - last not least - de Dansebegavede, som har Evner til den svare Ballettraning, opnaar, ved at sammenkade Traningen med Legemskulturen og den rytmiske Plastik, den fulde Udfoldelse af deres Talent. « ${ }^{13}$

Jenny Møller betonede i sin pædagogik desuden, at dansen skulle være et både følelsesmæssigt og personligt udtryk. Hendes undervisning sigtede derfor på at udvikle den enkelte elevs særlige evner. Om forholdet mellem det personlige udtryk og de tekniske og skønhedsmæssige krav udtalte hun: »Jeg holder Teknikken højt i Ære, men det er dog Folelsen, det oplevede, der skal finde sit Udtryk i Dansen, ellers bliver det hele blot en Rakke Trin og Attituder, der intet har med Kunst at gøre. «" ${ }^{14}$

Opsummerende kan det siges, at Agnete Bertram og i mindre udtalt grad Jenny Møller tilsluttede sig forestillingen om den kvindelige særart og stræbte efter at reali- 
sere en særlig kvindelig bevægelsesform, som betonede bevægelseskvaliteter som harmoni, rytme og ynde. Den skulle hos begge være sjæleligt opdragende og kompensere for fysisk og intellektuel træthed. Mens æstetikken for Agnete Bertram var funktionel og et middel til den åndelige og »hygiejniske « opdragelse, var den hos Jenny Møller tillige et kunstnerisk og ekspressivt mål i sig selv.

\section{Dans og kvindegymnastik som kropskulturelle genrer}

Hvor Agnete Bertrams gymnaster blev bærere af hendes særlige system for kvindegymnastik, havde Jenny Møller absolut ingen hensigt om at uddanne sine elever til 'Jenny Møller danserinder': »Der er intet jeg nødigere vil end at påtvinge mine unge Elever en bestemt Form ... de skal netop have Lov til at danse saaledes, som det falder dem naturligst, « ${ }^{15}$ Denne forskel gælder ikke blot i sammenligningen af Agnete Bertram og Jenny Møller, men karakteriserer desuden en genremæssig forskel mellem dans og kvindegymnastik. Hvis vi ser på de trykte mediers fotografiske fremstilling af gymnastikken fremstår den oftest som et system med illustrationer, der viser holdet i den korrekte udførelse af en given $\varnothing$ velse. For dansens vedkommende, fokuseres der derimod på den enkeltes præstation, ligesom eventuelle illustrationer viser enten variationer i udtrykket hos flere dansere i en opstilling eller eneren, den unge danserinde, som udmærker sig ved sit personlige udtryk.

På et mere overordnet plan er gymnastik defineret ved kropslige $\emptyset$ velser der henfører til en eller flere (anatomisk, fysiologisk eller æstetiske) standarder for $\varnothing$ velsernes udførelse. Gymnastik handler om kroppens formåen i forhold til øvelser. Gymnastikkens historie har vist forskellige former for gymnastiske systemer og traditioner, som har varieret meget i forhold til form og begrundelse, dvs. standarder for korrekthed. ${ }^{16}$ Til sammenligning er scenedansen i Europa siden renæssancen blevet betragtet som en kunstform i sin egen ret og dermed primært som et æstetisk udtryk. I dansen er $\varnothing$ velserne aldrig et mål i sig selv, men derimod et middel til opnåelse af et kunstnerisk ideal, hvor bevægelsen anses for at have et transformerende potentiale, der retter sig mod såvel de udøvende som tilskuerne. Dansen handler om at være krop i alle mulige former. I forhold til gymnastikken er opmærksomheden således forskudt fra den korrekt udførte $\varnothing$ velse til en interesse for kroppe(n) i bevægelse, samt for den helhed, som bevægelserne indgår $\mathrm{i}$.

I Agnete Bertrams egen forståelse holdt hendes kvindegymnastik sig inden for den gymnastiske genre. I forskellige sammenhænge gav hun den prædikater som legemskultur og naturlig, funktionel og akademisk gymnastik. På en journalists spørgsmål om hvordan hun definerede sit system, svarede hun: »Min Gymnastik er absolut ikke Plastik [..] Det er Gymnastik, det ser bare ikke grimt $u d \ll \cdot{ }^{17}$ Alligevel forstod store dele af publikum ikke hendes gymnastik ud fra en snæver gymnastikdefinition. I omtaler af Bertram-opvisninger er den hyppigt karakteriseret som plastik, dans, tempeldans, intellektuel skønhed, ynde og æstetik - begreber som med få undtagelser er knyttet til i kunstdansen. Agnete Bertrams kvindegymnastik udfordrede altså de gængse opfattelser og definitioner af gymnastik.

I scenedansens historie har det omvendt givet anledning til bekymring og kritik, når balancen mellem kunstdans og gymnastik 
er blevet forskubbet til fordel for sidstnævnte. Allerede balletmester og koreograf August Bournonville (1805-1878) noterede i sin koreografiske trosbekendelse: »Dansen kan ved musikkens hjolp hoeve sig til poesi, men også ved et overmål af gymnastik nedsynke til gøgleri ... ${ }^{18}$ Frygten for en udvendiggørelse af kunstdansen gennem overdreven brug af gymnastik, overlevede i begyndelsen af 1900-tallet. Således understregede den amerikanske danser Isadora Duncan i sin kritik af Émile Jaques-Dalcrozes 'gymnastique rhytmique', at ekspressivitet snarere end imitation var grundlaget for fremtidens dans. ${ }^{19}$ Et lignende synspunkt blev i 1918 formuleret fra et balletæstetisk udgangspunkt i Berlingske Tidendes anmeldelse af Emilie Walboms iscenesættelse af En Nat $i$ Agypten på Det kongelige Teater: »Det var det gymnastisk-rytmiske Moment, som her havde overtaget. Skønheden søgtes ikke her i den koreografiske teknik, men i Legemets Stillinger.$^{20}$

Anskuet som repræsentanter for to forskellige kropskulturelle genrer, viser sammenligningen af Agnete Bertrams kvindegymnastik og Jenny Møllers dans, hvorledes de definerer sig indenfor de genrespecifikke konventioner som f.eks. i betoningen af gruppen (gymnastik) overfor individet (scenedans), funktion overfor følelse og $\varnothing$ velse overfor udtryk. Der findes imidlertid også eksempler fra de to pædagogers virke i 1920erne og 1930erne på en overskridelse af de genremæssige bestemmelser, som uddyber fornemmelsen af slægtskab og overlapning i deres professionelle tilgang. For eksempel valgte Agnete Bertram i 1925 at flytte sine gymnaster ind i en teaterkontekst, idet en gruppe på ti Bertram-gymnaster optrådte i Scala-reyen Rosen Blusser. Efter denne enkeltstående optræden pointerede Agnete
Bertram ganske vist $i$ et interview, at der bag det umiddelbare plastiske udtryk var en strengt systematisk og funktionel tilgang: »Det Indtryk [af Plastic] har De maaske faaet i Scala. Men jeg kan sige, at ik$k e$ en eneste Øvelse er lavet, for at den skal tage sig $u d \ll .{ }^{21} \mathrm{Ti}$ år senere, i 1935, optrådte Jenny Møller i den Nordiske Olympiade i Ollerup som medvirkende i danseforestillingen Måneskinssonaten, der blev vist på friluftsscenen på stævnets afslutningsaften. ${ }^{22}$ Selv om heller ikke denne enkeltforeteelse betyder, at hendes dans bliver til gymnastik, kan de to tilsammen ses som eksempel på en overlapning mellem genrerne, hvad angår rammerne for deres iscenesættelse.

Vi forlader her genren som kontekst for sammenligningen af Agnete Bertram og Jenny Møller for i stedet at indplacere dem $i$ et større kulturelt felt.

\section{Scenisk dans som kulturelt felt}

Anskuet som et særligt felt for kulturel produktion kan det fælles anliggende i scenedansen defineres som en kamp om retten til at autorisere, hvad der gælder som dansekunst. Feltets agenter består af dansere, koreografer, danseanmeldere, danseforskere, dansepædagoger, producenter af danseforestillinger, impresarioer og teaterdirektører. Institutioner kan være scener for dans, kunststøtteordninger, danseuddannelser, foreninger og organisationer samt tidsskrifter og bøger om dans.

En historisk og kulturel undersøgelse af scenedansen i Danmark omkring 1920 viser, at den mest dominerende institution i feltet, Den Kongelige Danske Ballet, var under udfordring fra flere forskellige sider. Nationalballettens mangel på fornyelse betød, at dansen som kunstform stod i alvorlig fare for at blive sat på et sidespor af 
dansen i det $\varnothing v$ rige forlystelsesliv. Her boltrede dansekunstnere og artister fra ind- og udland sig til gengæld på privatteatre og revyscener.

Som velrenommeret dansepædagog og mentor for adskillige internationalt anerkendte dansekunstnere, indtog Jenny Møller en betydningsfuld om end marginal position i det samlede felt. Medvirkende til at sikre hende en position i dansens æstetiske domæne var foruden den professionsrettede undervisning hendes tilbagevendende elevopvisninger og lejlighedsvise koreografiske bidrag til egne og andres forestillinger på privatteatrenes scener. Denne placering blev forstærket af den sociale placering af klientellet i Jenny Møllers Danse Studie, der fortrinsvis tilhørte borgerskabet og diplomatiet. Til forskel fra Den Kongelige Ballet var hendes skole desuden i stand til hurtigt at tilpasse sig markedets behov, herunder den opblomstrende interesse for plastik, der i 1920erne bidrog til at opdrage frem for alt borgerskabets kvinder som bærere af den europæiske kulturarv. Heri lå en interesse for antikkens kropsidealer, som bl.a. ses illustreret i dagspressens annoncespalter forud for danseskolernes sæsonstart. Her optræder Jenny Møllers Danse Studie som ét blandt en række private institutter med tilbud om undervisning, som på forskellig vis kombinerer dans, plastik, gymnastik, rytmik og moderne selskabsdans. ${ }^{23}$

Balletten var samtidig under udfordring fra et nyopdukket fænomen, der særligt hørte hjemme på revyscenerne, nemlig 'dancing girls' ${ }^{24}$ Kulturdebatten i 1920erne gav genlyd af synspunkter på fænomenet 'girls', som var et begreb, der blev anvendt i såvel England, som i Frankrig, Tyskland og Danmark. Betegnelsen 'girl' henviste til en ny kvinderolle, hvori unge kvinder blev iscenesat og iscenesatte sig selv i det offentlige rum, det være sig det urbane, på stranden, på scenen eller på film. Til forskel fra de danserinder, der var uddannet hos Jenny Møller, var girls et massekulturelt fænomen. Prototypen på en girl var en ugift, selvforsørgende ung kvinde fra arbejderklassen, for hvem det moderne bylivs adspredelser var mere tillokkende end mand, børn og dobbeltarbejde. De foruroligende undertoner, der blev fremkaldt af girl-rollens forening af lillepiget uskyldighed og uforfærdet fremtræden med dens brud på et traditionelt kvindeligt livsmønster, blev forstærket i takt med transformationen fra girl som enkeltstående fænomen til en langt mere omfattende 'girls-kultur'. I det samlede dansefelt forblev girls-kulturen imidlertid marginal, idet den bl.a. i kraft af sit udspring i arbejderklassen ikke blev betragtet som kunst.

Opsummerende kan der peges på nogle fællesnævnere, som medvirker til at positionere plastikundervisningen og girls-kulturen anderledes end balletten i det samlede dansefelt. For det første er der det modernitetskritiske aspekt, som i begge subfelter er ganske fremtrædende, om end det klassemæssige grundlag er forskelligt. For det fremstår både dyrkelsen af de antikke længsler i offentligheden og fænomenet dancing girls som udtryk for en feminiseret underholdningskultur. ${ }^{25}$

\section{Kvindegymnastik som subfelt $i$ idratsfeltet}

Kvindegymnastik kan som kulturelt felt anskues som en kamp om retten til at definere den legitime »kvindelige « kvindegymnastik. Feltets agenter består af kvindelige (og i nogen grad mandlige) gymnastiklærere, gymnastik- og idrætsorganisationer, gymnastik- og idrætsforeninger, 
skolefolk, gymnastikfaglige sammenslutninger og tidsskrifter, uddannelsesinstitutioner, anmeldere af gymnastikopvisninger, inspektionsmyndigheder, læger og fysiologer og kvindelige gymnaster. Eksterne logikker fra omgivende felter, såsom det pædagogiske felt og det videnskabelige felt bet $\varnothing \mathrm{d}$ dog, at kvindegymnastikken kun havde en lille grad af autonomi. ${ }^{26} \mathrm{Men}$ også kvindegymnastikkens relationer til samtidens kvindebevægelse må medtænkes, hvis man skal forstå dens betydning.

Den moderne idræts gennembrud i slutningen af 1800-tallet skete samtidig med store omvæltninger i det danske samfund. Omvæltningerne som følge af det moderne gennembrud fik stor betydning for kvinders samfundsmæssige rolle og livsvilkår. Kvinderne gik fra at være umyndige til formelt medborgerskab, typisk illustreret med indførelsen af kvinders stemmeret i 1915. Opkomsten af særlige kvindeprofessioner og -uddannelser for kvinder gav de unge kvinder en helt ny mulighed for at få et selvstændigt liv uden for hjemmets fire vægge. Gymnastik og i mindre omfang sport blev for mange kvinder en vej ud i det offentlige rum dels som udøvere og dels som undervisere og ledere i såvel skolegymnastik som foreningsliv.

Mens kvindegymnastikkens første pionerer både bestod af kvinder og mænd (især skolefolk og læger), skete der fra omkring 1900 en feminisering, som slog stærkest igennem i København. Der blev etableret private og offentlige uddannelsesinstitutioner, som uddannede gymnastiklærerinder. Deres arbejdsfelt var dels skolegymnastikken, som blev delvist obligatorisk skolefag for piger i 1904 og dels den private og foreningsbaserede undervisning af voksne kvinder. I København blev der i årene omkring 1900 parallelt med de fælleskønnede foreninger etableret tre kvinde- lige gymnastik- og idrætsforeninger som i løbet af de følgende årtier talte en tusindtallig medlemsskare. En central konstituerende forestilling i feltet for kvindegymnastik var, at det var muligt at skabe en essentielt kvindelig kvindegymnastik. Hvori denne skulle bestå var dog særdeles omstridt, og de forskellige traditioner inden for kvindegymnastik, herunder Agnete Bertrams, blev agenter i kampene om retten til at definere den legitime kvindegymnastik. En anden central forestilling var, at kvinder havde et særligt og medfødt pædagogisk »blik« i forhold til kvindegymnastik, og den blev brugt i positioneringer af kvindegymnastik som en særlig profession for uddannede gymnastiklærerinder.

\section{Symbolsk kapital}

Socialt set kom både Agnete Bertram og Jenny Møller fra et intellektuelt mellemlag. Jenny Møller, hvis forældre havde tiltænkt hende en lærerindeuddannelse, blev i stedet autodidakt danser, koreograf og dansepædagog. Efter tilskyndelse fra Michail Fokin, hvem hun mødte og begyndte at studeres hos i eftersommeren 1918, oprettede hun en ballet skole i eget navn i 1919, der med tiden fik både en danserinde- og en lærerindeuddannelse. Agnete Bertram blev student i 1912 og læste derefter dansk, engelsk og gymnastik på universitetet. Derefter blev hun ansat som gymnastiklærerinde og -inspektrice i USG (Universitetets Studenter Gymnastikforening). Ligesom Jenny Møller drev hun fra 1920-1942 med succes et privat institut »Agnete Bertram Kvindegymnastikskole«, som i 1928-1933 blev udvidet med en gymnastiklærerindeuddannelse.

Både Agnete Bertram og Jenny Møller var agenter på et $\varnothing$ konomisk marked, hvor de var afhængige af betalende elever. Det 
er også formentlig i det lys, at man skal forstå Agnete Bertrams optræden i Scalarevyen og Jenny Møllers dans på den Nordiske Olympiade. Annoncering og markedsføring var et vilkår for dem, og positionerede begge deres skoler og systemer i aviser og blade. I forbindelse med Agnete Bertrams gymnastikopvisninger i København og provinsen blev der ofte bragt anmeldelser, reportager og interviews. Karakteristisk nok blev det altid omtalt, at Agnete Bertram var den første kvinde med universitetsbifag i gymnastik, hvilket derfor må betragtes som symbolsk kapital. Formålet med denne positionering var at legitimere hendes system som videnskabeligt. Tilsvarende skete der en positionering af hendes titel »Universitetsgymnastiklærerinde «. Hvis journalisten ikke positionerede hendes akademiske kapital, gjorde hun det selv. ${ }^{27}$ Herved opnåede hun en position i overlappet mellem kvindegymnastik og det videnskabelige felt, som også betød en distancering fra mange af de $\varnothing v$ rige aktører i kvindegymnastikken, som var tættere knyttet enten til den mere sportsorienterede del af idrætsfeltet eller til den såkaldt folkelige gymnastiktradition i idrætsfeltet.

Det aspekt af Jenny Møllers uddannelse, der fremhæves i næsten al presseomtale af hendes virksomhed og som derfor må betragtes som symbolsk kapital, er hendes status som elev af Michail Fokin. Fokin blev under sit ophold i Danmark mødt med stærk modvilje af nationalballettens ledelse, som frygtede en korrumpering af den nationale balletarv efter Bournonville. Af samme grund fik han kun få danske elever, mens udenlandske dansere fra bl.a. Sverige, Norge og Tyskland rejste hertil for at modtage privatundervisning. For Jenny Møller, der som den eneste dansker offentligt kundgjorde sin optagelse som elev af den russiske balletreformator, blev Fokin en vigtig mentor. Da Fokin vendte tilbage til Danmark i 1925 var opinionen blevet vendt til hans fordel og hans balletter blev hyldet som ballettens moderne gennembrud. At Fokin ved samme lejlighed lod sig fotografere til ugebladene som gæst ved sin danske elevs privatskole, bekræftede og bestyrkede mentorskabets funktion som symbolsk kapital for Jenny Møller.

De to kvinders symbolske kapital kom også til udtryk i deres internationale relationer og positioneringer. Agnete Bertram opbyggede et stort internationalt netværk, og opnåede anerkendelse på gymnastik og foredragsturneer i England, Polen, Norge, Sverige, Holland, Finland, Belgien, Frankrig, USA og Canada. ${ }^{28}$ I hundredvis af udenlandske, især engelske og amerikanske gymnastiklærerinder kom til Danmark for enkeltvis eller $\mathrm{i}$ grupper at deltage $\mathrm{i}$ korte kurser på Bertram-skolen. Således havde hun i 1928200 engelske lærerinder på kursus. ${ }^{29}$ En del af de 71 kvinder, som fulgte Agnete Bertrams etårige gymnastiklærerindeuddannelse i årene 1928-1933, deltog i udbredelsen af Bertram-gymnastikken uden for Danmarks grænser. Adskillige havde udenlandsk baggrund; der var elever fra Sverige, Norge, Palæstina, Bulgarien, Tyrkiet og Litauen, og flere af dem rejste hjem og oprettede Bertram-skoler.

I sammenligning med den internationale rækkevidde af Agnete Bertrams system var Jenny Møller mindre betydningsfuld. Når man tager hendes autodidakte uddannelse $\mathrm{i}$ betragtning havde hun alligevel en ganske betragtelig indflydelse på datidens dansekunst, også uden for Danmarks grænser. Som elev hos Fokin fik hun en række betydningsfulde kontakter blandt udenlandske dansere og ved sit engagement hos Max Reinhardt i Tyskland i 1921 konsoli- 
derede hun den internationale dimension $\mathrm{i}$ hendes udsyn og professionelle netværk. Det er derfor næppe tilfældigt, at en række af de elever, der tog en professionsuddannelse hos Jenny Møller, gjorde professionel karriere i udlandet. Blandt disse kan nævnes Karen Marie Anders Jensen (som optrådte i bl.a. Frankrig og Spanien), Birger Bartholin og Vibeke Rørvig (som uden for Danmark fortrinsvis gjorde sig gældende i Frankrig). De to elever, der opnåede størst anerkendelse i international henseende, russificerede deres navne efter at være rejst til Paris som dansere hos efterkommerne efter Diaghilevs Ballets Russes. Her blev Rigmor Strøm til Nina Stroganova, der senere blev en skattet balletpædagog i USA. Ellen Wittrup blev under kunstnernavnet Helen Kirsova først solodanserinde i Grev de Basils Ballets Russes og etablerede dernæst Kirsova Balletten i Australien i 1940erne.

\section{Det kvindelige medborgerskab}

Kvinders vej til medborgerskab har været mere omstændelig og langsom end mænds. De fik således stemmeret og dermed politisk medborgerskab uden forinden at have haft fuldt civilt medborgerskab, dvs. samme ret til arbejde, uddannelse og løn. For at få et fuldstændigt billede af, hvad der skaber en fuldgyldig medborger, kan man unders $\varnothing$ ge den politiske praksis. Vi anvender her et bredt politikbegreb, som betyder, at alle handlinger rettet mod offentligheden, regnes som politik. ${ }^{30}$ Hermed bliver det muligt at indfange kvinders politiske medborgerskab, således som det fandt sted gennem deres handlinger på arbejdspladser, i organisationer, i kulturlivet eller i andre ikke-politiske institutioner, hvor der var en stræben efter forandring.

Med medborgerskabsbegrebet som op- tik kan såvel Agnete Bertrams kvindegymnastik som Jenny Møllers danseundervisning ses som en arena for kvinders politiske handlen. Derved bliver det muligt at se kvinders forskelligartede involvering $\mathrm{i}$ kropskulturelle træningssystemer som en mulighed for en stræben efter at udvide grænserne for deres medborgerskab både før og efter det opnåede politiske medborgerskab.

I både gymnastikkens, idrættens og dansens praksis kunne kvinderne erfare en større grad af kropslig frigørelse end tidligere. Med denne frigørelse voksede også vigtigheden af en beherskelse af det kropslige udtryk. Den amerikanske danseforsker Nancy Lee Chalfa Ruyter bemærker, hvorledes der parallelt med kvindernes indtagelse af det offentlige rum i USA kan konstateres en stigende interesse for træningssystemer, der handler om ekspression eller udtryk. Disse systemer, hævder hun, udgjorde en ramme, der tillod borgerskabets kvinder at vie opmærksomhed til deres krop og gav dem desuden redskaber, hvormed de kunne præsentere sig offentligt med et repertoire af fysiske og ekspressive aktiviteter, vel at mærke uden at overskride rammerne for det sømmelige. ${ }^{31}$

De kvinder, som engagerede sig i de kvindelige gymnastikforeninger som undervisere og/eller ledere, var i en anden forstand med til at udvide rammerne for det kvindelige medborgerskab. Gennem foreningslivet fik kvinderne indblik og praktiske færdigheder i de demokratiske processer, som gjaldt i samfundet uden for. I foreningerne kunne de $\varnothing$ ve sig $\mathrm{i}$ at være medborgere med de rettigheder og pligter, som det indebar. De kvindelige gymnastikforeninger støttede desuden kvindebevægelsens kamp for politisk og socialt medborgerskab, og kvindebevægelsen støttede på sin side jævnligt kvindegymnastik- 
kens feminisering og selvstændighedsstrategi.

Mens de kvindelige foreningsledere så det som en medborgerpligt at gøre fysisk aktivitet tilgængelig for andre kvinder og især for kvinder fra lavere sociale lag, rekrutterede Agnete Bertram og Jenny Møller hovedsaligt deres elever blandt borgerskabets kvinder. Danseskolerne var typisk på private hænder og mange var som $\mathrm{i}$ Jenny Møllers tilfælde ejet af kvinder, der lærte at begå sig som selvstændigt erhvervsdrivende. Det samme gjaldt for Agnete Bertram, som aldrig eksplicit positionerede synspunkter om det kvindelige medborgerskab, men man kan sige at hun i udstrakt grad praktiserede det selv.

\section{Konklusion}

Som det er fremgået af analysen af de bevægelsesmæssige kvaliteter i Agnete Bertram og Jenny Møllers undervisning, er der adskillige fællestræk. Et af dem er, at der er tale om et møde mellem flere forskellige diskurser: ud over den æstetisk dannende og kvindelighedskonstruerende, en terapeutisk, der hyldede disciplinen som en helende kunstform i stand til at udbedre de skader, civilisationen havde påført mennesket, og en hygiejnisk, der forbandt samme civilisations kropslige såvel som mentale sundhed med dyrkelsen af de klassiske idealformer. Et andet fællestræk, som kan ses i forlængelse af de to pædagogers positioner som 'outsidere' i felterne for henholdsvis kvindegymnastik og scenisk dans, er den villighed, hvormed de overskrider deres fags genrekonventioner i forhold til f.eks. markedsføring.

Endelig leder sammenligningen af Agnete Bertram og Jenny Møllers professionelle virker os til den konklusion, at kvindegymnastikken og danseundervisningen $\mathrm{i}$ 1920-30erne udgjorde et væsentligt og hidtil underbelyst bidrag til udbygningen af fuldgyldigt medborgerskab for kvinder.

\section{Noter}

1. Begrebet plastik benyttes her om en kropskulturel disciplin, der nød udbredt popularitet især blandt kvinder i 1900-tallets første årtier. Igennem plastikken opøvedes en evne til og færdighed i udførelse af smukke legemsbevægelser, indtagelse af tvangfri, sikker holdning efter gældende skønhedsbegreber til dels også i stillinger, der mindede om billedhuggerkunstens frembringelser.

2. Se f.eks. Ungdom og Idrat nr. 9, 1914 og samme nr. 14, 1923.

3. Den svejtsiske musikpædagog Émile Jaques-Dalcroze (1865-1950) udviklede en bevægelsesrytmisk tilgang til sin musikundervisning.

4. I artiklen og i vores phd. afhandlinger er sociologen Pierre Bourdieus feltbegreb en central teoretisk indfaldsvinkel. Med feltbegrebet kan scenisk dans og kvindegymnastik analytisk konstrueres som subfelter i henholdsvis kunstfeltet og idræts-

feltet. Se Karen Vedel, Ballethistoriens Anden. Moderne scenisk dans i Danmark 1900-1975 « (Institut for Kunst og Kulturvidenskab, Københavns Universitet 2004) og Anne Lykke Poulsen, »Den kvindelige Kvinde«: Kampe om kvindelighed, medborgerskab og professionalisering $i$ dansk kvindegymnastik 1886-1940 (København, 2005).

5. Gymnastikfilmen blev oprindelig skabt som en stumfilm afspillet med klaverakkompagnement. Filmen er i dag overspillet til video (som befinder sig på Københavns Universitet, Institut for Idræts bibliotek).

6. Jennifer Hargreaves, Sporting Females (London og New York, 1994), s. 44.

7. Birgitte Possing, Køn og kvindelighed - hvilke historiske kategorier? I: Den jyske Historiker nr. 58-59, 1992. 
8. BT 17.4.1923.

9. Agnete Bertram, Hjemmegymnastik (København, 1927) s. 15.

10. Johannes Lindhard, Gymnastisk Selskabs Aarsskrift 1913-14, 1914.

11. Morgenbladet Christiania 23.3.1912.

12. »Hos fru Walbom«, Nationaltidende 23.1.1920.

13. Program for Jenny Møllers Dansestudie 1932-33.

14. Vore Damer 30.3.1928.

15. ibid.

16. Søren Damkjær, »Kunstens og idrættens æstetik «. I: Søren Damkjær og Olav Ballisager (red.), Kroppens ide (Århus, 2003) s. 53ff.

17. Kobenhavn 18.11.1923.

18. August Bournonville, Mit Teaterliv bind 2, (Кøbenhavn, 1979), s. 263.

19. Ann Daly, Done into Dance. Isadora Duncan in America (Middletown, 1995), s. 84.

20. Julius Clausen, Berlingske Tidende 29.4.1918. Forestillingen havde koreografi af Emilie Walbom efter Michail Fokin.

21. Kobenhavn 7.6.1925.

22. Program: Landsstævnet i Ollerup 1935, Nordisk
Olympiade. De danske Gymnastik og Idrætsforeninger 25.-28. juli 1935)

23. Annoncespalterne i Politiken 27.9.1925.

24. Karen Vedel, 'Dancing Girls'. I: Erik Hvidt (red.): Revy til tiden (København, 2004).

25. Andreas Huyssen, After the Great Divide (Bloomington, 1986) s.44 ff

26. Anne Lykke Poulsen, En kamp om kvindelighed Bourdieus feltbegreb som værktøj. I: Dansk Sociologi nr. 2, 2004.

27. For eksempel Kobenhavn, 29.4.1923 samt BT 17.4.1923.

28. Viggo Bertram, En indvandrerslagt. Slagten Bertram gennem 253 år (København, 1984).

29. Nationaltidende 25.10.1927 og B.T. 19.7.1928.

30. Christina Florin og Lars Kvarnström, Kvinnor på gränsen till medborgarskap. I: C. Florin og L. Kvarnström (red.), Genus, medborgarskap och offentlig politik, 1848-1998. Svenska samhället $i$ omvandling (Stockholm, 2001), s. 13-40.

31. Nancy Lee Chalfa Ruyter, The Cultivation of Bo$d y$ and Mind in Nineteenth-Century American Delsartism (Westport, 1999) s. xv11. 